\title{
Erratum to: \\ Myth \#3: Healthcare Institutions as Well \\ as the Overall System Can Be Fixed \\ by Bringing in the Great Leader
}

\author{
Anna Maria Livia Colao, Pasquale Antonio Riccio, Antonio Botti, \\ Aurelio Tommasetti, Massimo Sargiacomo, Antonio D'Andreamatteo \\ and Luca lanni
}

\author{
Erratum to: \\ Chapter 6 in: P. Adinolfi and E. Borgonovi (eds.), \\ The Myths of Health Care, \\ https://doi.org/10.1007/978-3-319-53600-2_6
}

The original version of the book was inadvertently published with the following errors in Chapter 6, which now have been corrected:

Two of three contributing author names, "Antonio D'Andreamatteo" and "Luca Ianni" of Section 3, which were missing in the Table of Contents and the chapter listing, now have been included.

In Section 3, the incorrect author name "Ianni Luca" has been changed to read as "Luca Ianni."

The updated online version of this chapter can be found at

https://doi.org/10.1007/978-3-319-53600-2_6 